\title{
Genetic differentiation between natural and hatchery populations of Manila clam (Ruditapes philippinarum) based on microsatellite markers
}

\author{
K. Xing ${ }^{1}$, M.L. Gao ${ }^{2}$ and H.J. Li ${ }^{3}$ \\ 'Department of Fishery Resource, Marine Technology and Environment College, \\ Dalian Ocean University, Dalian, China \\ ${ }^{2}$ Department of Biotechnology, School of Biological and Food Engineering, \\ Dalian Polytechnic University, Dalian, China \\ ${ }^{3}$ Key Laboratory for Ecological Environment in Coastal Areas (SOA), \\ National Marine Environmental Monitoring Center, Dalian, China \\ Corresponding author: H.J. Li \\ E-mail: hjli@nmemc.gov.cn \\ Genet. Mol. Res. 13 (1): 237-245 (2014) \\ Received November 21, 2012 \\ Accepted May 16, 2013 \\ Published January 17, 2014 \\ DOI http://dx.doi.org/10.4238/2014.January.17.7
}

\begin{abstract}
Manila clam (Ruditapes philippinarum) is one of the major aquaculture species around the world and supports an important segment of the aquaculture industry in China. In this study, we used ten microsatellite markers to detect genetic diversity within six $R$. philippinarum populations and genetic differentiation between them. A total of 109 alleles were detected across all loci. Compared to wild populations $\left(N_{\mathrm{A}}=8.4-9.1\right.$ alleles/locus, $\left.H_{\mathrm{E}}=0.75-0.77, H_{\mathrm{O}}=0.67-0.73\right)$, hatchery stocks showed less genetic variation as revealed in lower number of alleles and lower heterozygosity $\left(N_{\mathrm{A}}=7.4-7.5\right.$ alleles/locus, $H_{\mathrm{E}}=0.72-$ $\left.0.75, H_{\mathrm{O}}=0.68-0.70\right)$, indicating that a bottleneck effect has occurred in hatchery history. Significant genetic differentiation was observed between cultured stocks $(\mathrm{P}<0.05)$, and between cultured and wild populations ( $\mathrm{P}$ $<0.05)$. Phylogenetic analysis showed a clear separation of the northern three populations and the southern three populations, suggesting that
\end{abstract}


geographically separated populations of $R$. philippinarum could be genetically differentiated with limited genetic information exchanged between them. The information obtained in this study indicates that the northern and southern populations of $R$. philippinarum should be managed separately in hatchery practices for the preservation of genetic diversity in wild populations.

Key words: Ruditapes philippinarum; Microsatellite; Genetic diversity; Wild population; Hatchery stock; Genetic differentiation

\section{INTRODUCTION}

The Manila clam Ruditapes philippinarum is a bivalve mollusk of the family Veneridae native to the Indo-Pacific region. China has cultivated the Manila clam for a thousand years, with current annual production of 1.8 million tons, accounting for about $80 \%$ of mudflat fishery production in China (Zhang and Yan, 2006). R. philippinarum has also been used for marine environmental monitoring through the 'mussel watch' program in China. The popularity of this organism as a sentinel derives from several aspects, such as its wide distribution, sessile life style, and filter-feeding habit that accumulates contaminants from seawater. Therefore, R. philippinarum has been the focus of research in genetics, biochemistry, physiology, and ecology. Despite its commercial and ecological importance, little information is available about the genetic diversity and population structure of $R$. philippinarum in China.

An important challenge for the culture of any species is to control the loss of genetic variability, commonly caused by the founder effect (Marchant et al., 2009). The high fecundity (usually more than $1 \times 10^{6}$ eggs per female) of the mature clam and the artificially high survival rate of juvenile individuals in a culture environment ensure that sufficient seed for each year's production may be derived from only a small number of parents. When small numbers of breeder are used, or the contribution of each parent is unbalanced, or related individuals are mated, there may be a decrease in genetic variability of farmed stocks (Boudry et al., 2002; Li et al., 2004). The effects of inbreeding and genetic drift on a hatchery population with a limited number of captive stocks may result in a decrease in the quality of commercially important traits (e.g., growth rate, pathogen resistance, and maximum size). Therefore, for successful hatchery management, it is important to monitor the genetic profile of hatchery stocks during hatchery rearing.

Characterized as highly variable, neutral, and codominant systems amenable to genotyping by polymerase chain reaction (PCR), microsatellites emerged as genetic markers for precise identification of populations and individuals (Weber and May, 1989; Li et al., 2007a). Over the past decade, microsatellite markers have been extensively used to evaluate the genetic diversity and structure of farmed aquaculture species, such as Atlantic salmon (Norris et al., 1999), tiger shrimp (Xu et al., 2001), flat oyster (Launey et al., 2002), Pacific abalone (Hara and Sekino, 2007), and bay scallop (Wang et al., 2007). In the present study, we used ten microsatellite markers to estimate the level of genetic diversity within four wild populations and two hatchery stocks of Manila clam, and to compare the degree of genetic differentiation between them.

\section{MATERIAL AND METHODS}

\section{Sampling}

We surveyed four wild and two cultured populations of the Manila clam (Figure 1). 
The wild population samples were collected from Dalian in Liaoning Province (DL, $\mathrm{N}=$ 52), Lianyungang in Jiangsu Province (LYG, $N=41$ ), Ningbo in Zhejiang Province (NB, $\mathrm{N}=44$ ), and Pingtan in Fujian Province (PT, $\mathrm{N}=48$ ). Two cultured stocks were collected from Zhuanghe $(\mathrm{ZH}, \mathrm{N}=52)$ and Qingdao $(\mathrm{QD}, \mathrm{N}=56)$. The $\mathrm{ZH}$ hatchery population was founded in 2006 using hatchery-reared broodstocks, and no selected strains or lines have been established. No details as regards the founding and maintenance of the QD hatchery stock are available; however, the parents of the QD cultured stock have been hatchery-propagated over several generations in northern China.

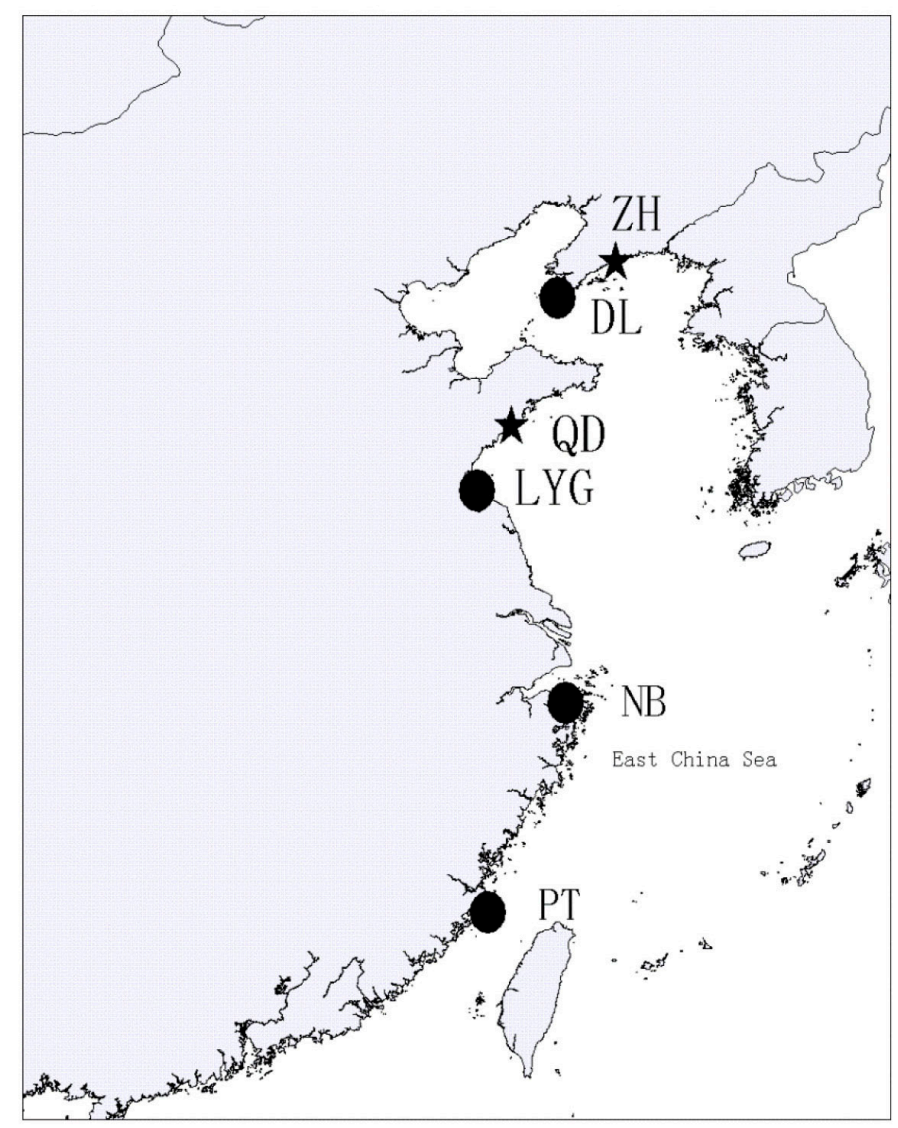

Figure 1. Map showing the locations and abbreviated names of four wild populations (circles) and two cultured populations (stars). $\mathrm{DL}=$ wild population of Dalian; $\mathrm{LYG}=$ wild population of Lianyungang; $\mathrm{NB}=$ wild population of Ningbo; PT = wild population of Pingtan; $\mathrm{ZH}=$ cultured population of Zhuanghe; $\mathrm{QD}=$ cultured population of Qingdao.

\section{DNA extraction and microsatellite analysis}

Genomic DNA was extracted from adductor muscles. Preserved tissue (about $100 \mathrm{mg}$ ) was digested with $1 \%$ SDS and $10 \mu \mathrm{g} / \mathrm{mL}$ proteinase $\mathrm{K}$ in $500 \mu \mathrm{L}$ STE buffer $(10 \mathrm{mM}$ Tris- 
$\mathrm{HCl}, \mathrm{pH} 8.0,100 \mathrm{mM} \mathrm{NaCl}, 1 \mathrm{mM} \mathrm{EDTA})$ for $3 \mathrm{~h}$ at $55^{\circ} \mathrm{C}$. The reaction mix was extracted twice with phenol-chloroform-isoamyl alcohol (25:24:1), and once with chloroform-isoamyl alcohol (24:1). DNA was precipitated with ethanol, washed with $70 \%$ ethanol, air-dried, and then suspended in distilled water. A total of 10 microsatellite markers (Table 1) were used in this study. PCRs were performed in a thermal cycler (PTC-100, Bio-Rad, USA) in a total volume of $20 \mu \mathrm{L}$ containing $0.75 \mathrm{U}$ Taq DNA polymerase (Takara), 1X PCR buffer, $0.2 \mathrm{mM}$ dNTP mix, $1.5 \mathrm{mM} \mathrm{MgCl}, 0.5 \mu \mathrm{M}$ of each primer, and about $50 \mathrm{ng}$ template DNA. The PCR program was set at $5 \mathrm{~min}$ at $95^{\circ} \mathrm{C}$ followed by 35 cycles of $30 \mathrm{~s}$ at $94^{\circ} \mathrm{C}, 30 \mathrm{~s}$ at the primerspecific annealing temperature listed in Table 1 , and $30 \mathrm{~s}$ at $72^{\circ} \mathrm{C}$, with a final extension for 10 min at $72^{\circ} \mathrm{C}$. Amplification products were separated on a $12 \%$ non-denaturing polyacrylamide gel at $300 \mathrm{~V}$ for $1.5-2 \mathrm{~h}$, stained with ethidium bromide, and visualized under ultraviolet light.

\begin{tabular}{|c|c|c|c|c|c|}
\hline Locus & Primer sequence $\left(5^{\prime}-3^{\prime}\right)$ & Repeat motif & GenBank No. & No. of alleles & References \\
\hline Asaril6 & $\begin{array}{l}\text { F: GCTCGAGTCTGATTGGCTACTTGAA } \\
\text { R: GGTATCTAGTCAGCTCTTGCAGTA }\end{array}$ & $(\mathrm{CT})_{12}$ & $\mathrm{AB} 257421$ & 8 & Yasuda et al., 2007 \\
\hline Asari24 & $\begin{array}{l}\text { F: CCTACGACATGTGGGTTATTT } \\
\text { R: TGTTTTACCTGTCCATCATTCA }\end{array}$ & $(\mathrm{GT})_{5} \mathrm{CT}(\mathrm{GT})_{3}$ & AB257423 & 6 & Yasuda et al., 2007 \\
\hline Asari55 & $\begin{array}{l}\text { F: TGGCTTTGTCAATTGTGTATTGTG } \\
\text { R: GACAAATTGGCTTTATTTGGAGG }\end{array}$ & $\mathrm{A}_{9} \ldots(\mathrm{CTT})_{8}$ & AB257427 & 14 & Yasuda et al., 2007 \\
\hline Asari62 & $\begin{array}{l}\text { F: AGTTGTACAGCAGCTCAGCAT } \\
\text { R: CAAATAACTAAACATTTTCAGACTGC }\end{array}$ & $(\mathrm{CT})_{7} \mathrm{C}_{3}(\mathrm{CT})_{5}(\mathrm{GA})_{3}$ & AB257428 & 10 & Yasuda et al., 2007 \\
\hline Asari64 & $\begin{array}{l}\text { F: GTATCTGAATGGGTTGTTATTGTGAA } \\
\text { R: GCAAAATCATTTCGTTTGATGC }\end{array}$ & $(\mathrm{CT})_{2} \mathrm{C}_{2}(\mathrm{GA})_{12}$ & AB257429 & 8 & Yasuda et al., 2007 \\
\hline KTp 5 & $\begin{array}{l}\text { F: ACAACTAGTATGTCAGGTCAA } \\
\text { R: GTTTTTCACAAGAAGATTTT }\end{array}$ & $(\mathrm{TG})_{5} \mathrm{TT}(\mathrm{TG})_{6}$ & EF109755 & 10 & An et al., 2009 \\
\hline KTp19 & $\begin{array}{l}\text { F: TTAACGCTAAACACAACACCT } \\
\text { R: AAATGCAACAGCGTAATAAAG }\end{array}$ & $(\mathrm{TG})_{3} \mathrm{CG}(\mathrm{TG})_{10}$ & EF109760 & 9 & An et al., 2009 \\
\hline KTp 22 & $\begin{array}{l}\text { F: AAGTAACATGCGAATTGAAAA } \\
\text { R: AACTGTGCTTGCCTGTAGATA }\end{array}$ & $(\mathrm{CAA})_{7}$ & EF109761 & 16 & An et al., 2009 \\
\hline KTp26 & $\begin{array}{l}\text { F: GCATATAGCGATTCACCTGT } \\
\text { R: GCTGTTCCATACAAGAAGTCA }\end{array}$ & $(\mathrm{TG})_{10}$ & EF109765 & 13 & An et al., 2009 \\
\hline KTp30 & $\begin{array}{l}\text { F: GAAAAGATTTGGGACTTGTGT } \\
\text { R: GCCGTTTAAATCGACCTG }\end{array}$ & $(\mathrm{TG})_{11}$ & EF109766 & 11 & An et al., 2009 \\
\hline
\end{tabular}

\section{Statistical analysis}

For each locus in each population, the standard indices, including the number of alleles $\left(N_{\mathrm{A}}\right)$, allelic and genotypic frequencies, and expected $\left(H_{\mathrm{E}}\right)$ and observed $\left(H_{\mathrm{O}}\right)$ heterozygosities were calculated using GENEPOP 3.4 (Raymond and Rousset, 1995). We also estimated an overall inbreeding coefficient ( $f$ ) (Weir and Cockerham, 1984) for each population and locus, by evaluating the significance through random allelic permutation procedures (minimum: 10,000 permutations) using FSTAT 2.9.3 (Goudet, 2001). A nonparametric analysis of variance (Mann-Whitney U-test) was performed to test for differences in the average values of $N_{\mathrm{A}}$ and $H_{\mathrm{E}}$ between the hatchery and wild populations using SPSS 10.0. Exact P value for testing conformity of genotypes with Hardy-Weinberg equilibrium (HWE) and linkage disequilibrium were estimated by the Markov chain method (1000 dememorization steps, 1000 batches, 1000 iterations per batch) employing GENEPOP. The significance levels were adjusted for sequential Bonferroni's correction (Rice, 1989). To determine the amount of genetic drift, the effective size of the Chinese hatchery stocks $\left(N_{\mathrm{E}}\right)$ was analyzed. Analysis of molecular vari- 
ance (AMOVA) was calculated using the Arlequin 3.0 software (Excoffier et al., 2005). The extent of population differentiation was examined by calculating fixation indices based on an infinite allele model and a stepwise mutation model. For the former, the Microsatellite Analyzer (MSA) computer program (Dieringer and Schlötterer, 2003) was used to calculate conventional $F_{\mathrm{ST}}$ values. The values of $F_{\mathrm{ST}}$ were tested for significant departure from zero using random permutation procedures (1000 permutations). For the latter, $R_{\mathrm{ST}}$ values (Slatkin, 1995) were calculated using Arlequin. Departure of $R_{\mathrm{ST}}$ estimates from zero was tested with 1000 permutations. A neighbor-joining (NJ) tree was constructed based on $F_{\mathrm{ST}}$ using the MEGA 4.0 software (Tamura et al., 2007).

\section{RESULTS}

\section{Genetic diversity in four wide populations and two cultured stocks}

A total of 109 alleles were detected at the ten microsatellite loci across the six sets of samples. KTp22 with 16 alleles was the most polymorphic microsatellite, while Asari24 was the least variable with only 6 alleles. The allele number at each locus varied significantly in different sample sets (Table 2). The DL population displayed the highest allele number $(9.10 \pm$ $2.64)$, followed by LYG $(8.5 \pm 1.90), \mathrm{NB}(8.50 \pm 2.51)$ and PT $(8.40 \pm 2.07)$. The two cultured populations (ZH and QD) showed lower allele numbers (7.50 \pm 1.51 and $7.40 \pm 1.17$, respectively). The wild populations (DL, LYG, NB, and PT) showed significantly higher allele richness than the cultured populations (ZH and QD) (Mann-Whitney U-test, $\mathrm{P}<0.05$ ). Compared to the $N_{\mathrm{A}}$ observed, the $N_{\mathrm{E}}$ at each locus was lower, indicating substantial unevenness in allele frequencies. The mean $H_{\mathrm{O}}$ was 0.68 and 0.70 in the hatchery populations, and ranged from 0.67 to 0.73 in the wide populations. However, the $H_{\mathrm{O}}$ difference between wild and hatchery populations is not statistically significant $(\mathrm{P}>0.05)$.

The observed genotype frequencies were tested for agreement with HWE (Table 2). After sequential Bonferroni's correction for multiple tests, among the 60 population-locus cases (6 populations $\mathrm{x} 10$ loci), 18 cases violated the equilibrium $(\mathrm{P}<0.005)$, all resulting in heterozygote deficiencies. Generally, more markers departed from HWE in the cultured stocks than in the wild populations. In the PT wild population, only the KTp22 marker did not conform to HWE, while in the QD-cultured stocks, five loci showed significant $(\mathrm{P}<0.005)$ departure from HWE. Estimates of $N_{\mathrm{E}}$ using the mean $F_{k}$ values are presented in Table 3. The $N_{\mathrm{E}}$ for the two cultured stocks (ZH and QD) was 59.9 and 48.2, respectively.

\section{Population differentiation}

$F_{\mathrm{ST}}$ and $R_{\mathrm{ST}}$ were used to estimate the population structure of the Manila clam (Table 4). Both showed that the tested populations of Manila clam were significantly $(\mathrm{P}<0.05)$ differentiated. AMOVA analysis showed that $20.1 \%$ of total genetic variation originated from betweenpopulation variation, while the within-population variation explained $80.9 \%$ of total variation. Genetic differentiation between populations was analyzed using $F_{\mathrm{ST}}$ and corrected average pairwise differences. All estimates of pairwise $F_{\mathrm{ST}}$ were statistically significant $(\mathrm{P}<0.05)$. An NJ phylogenetic tree was constructed using the $F_{\mathrm{ST}}$ genetic distance matrix. The 3 northern populations (DL, ZH, and QD) formed one group, while the 3 southern populations (LYG, NB and PT) clustered into another (Figure 2). 
Table 2. Summary statistics for genetic variation at 10 microsatellite loci in six populations of Manila clam.

\begin{tabular}{|c|c|c|c|c|c|c|c|c|c|c|c|c|}
\hline Population (N) & & Asaril6 & Asari24 & Asari55 & Asari62 & Asari64 & $K T p 5$ & KTp19 & $K T p 22$ & $K T p 26$ & KTp30 & Average \\
\hline \multirow[t]{5}{*}{ DL (52) } & $N_{\mathrm{A}}$ & 7 & 6 & 12 & 10 & 6 & 8 & 7 & 12 & 13 & 10 & 9.10 \\
\hline & $A R$ & 5.2 & 4.8 & 9.2 & 7.2 & 4.5 & 6.1 & 4.9 & 9.6 & 9.2 & 7.5 & 6.82 \\
\hline & $H_{\mathrm{E}}$ & 0.71 & 0.79 & 0.83 & 0.72 & 0.71 & 0.86 & 0.72 & 0.86 & 0.81 & 0.70 & 0.77 \\
\hline & $H_{\mathrm{O}}^{\mathrm{E}}$ & 0.64 & 0.65 & 0.69 & 0.60 & 0.72 & 0.70 & 0.68 & 0.71 & 0.68 & 0.68 & 0.67 \\
\hline & $f^{0}$ & 0.06 & $0.13 *$ & 0.03 & 0.02 & -0.01 & 0.03 & 0.04 & $0.19 *$ & $0.15^{*}$ & 0.02 & 0.02 \\
\hline \multirow[t]{5}{*}{ LYG (41) } & $N_{\mathrm{A}}$ & 6 & 6 & 11 & 9 & 7 & 9 & 7 & 11 & 9 & 10 & 8.50 \\
\hline & $A \stackrel{A}{R}$ & 4.8 & 4.6 & 9.6 & 7.8 & 5.8 & 7.1 & 5.2 & 8.4 & 6.5 & 7.8 & 6.76 \\
\hline & $H_{\mathrm{E}}$ & 0.61 & 0.85 & 0.72 & 0.82 & 0.66 & 0.70 & 0.84 & 0.88 & 0.64 & 0.78 & 0.75 \\
\hline & $H_{\mathrm{O}}^{\mathrm{E}}$ & 0.57 & 0.83 & 0.69 & 0.72 & 0.56 & 0.64 & 0.85 & 0.75 & 0.66 & 0.76 & 0.70 \\
\hline & $f^{\circ}$ & $0.13^{*}$ & 0.01 & 0.10 & $0.12^{*}$ & 0.08 & 0.06 & -0.01 & 0.06 & -0.03 & 0.02 & 0.05 \\
\hline \multirow{5}{*}{ NB (44) } & $N_{\mathrm{A}}$ & 7 & 5 & 13 & 8 & 6 & 9 & 7 & 12 & 9 & 9 & 8.50 \\
\hline & $A R$ & 6.4 & 4.4 & 11.2 & 6.5 & 5.5 & 7.6 & 5.9 & 10.2 & 7.8 & 7.4 & 7.29 \\
\hline & $H_{\mathrm{E}}$ & 0.71 & 0.81 & 0.77 & 0.81 & 0.72 & 0.78 & 0.88 & 0.86 & 0.57 & 0.77 & 0.77 \\
\hline & $H_{\mathrm{O}}$ & 0.72 & 0.84 & 0.64 & 0.74 & 0.68 & 0.80 & 0.75 & 0.88 & 0.52 & 0.70 & 0.73 \\
\hline & $f^{0}$ & -0.02 & -0.03 & $0.17^{*}$ & 0.09 & 0.05 & -0.03 & $0.15^{*}$ & -0.02 & $0.09 *$ & 0.09 & 0.02 \\
\hline \multirow{5}{*}{ PT (48) } & $N_{\mathrm{A}}$ & 8 & 6 & 13 & 8 & 6 & 8 & 7 & 10 & 9 & 9 & 8.40 \\
\hline & $A \stackrel{A}{A}$ & 7.2 & 4.6 & 11.2 & 6.8 & 4.9 & 6.8 & 5.8 & 8.2 & 7.4 & 7.6 & 7.05 \\
\hline & $H_{\mathrm{E}}$ & 0.72 & 0.81 & 0.75 & 0.81 & 0.68 & 0.71 & 0.89 & 0.87 & 0.59 & 0.80 & 0.76 \\
\hline & $H_{\mathrm{O}}^{\mathrm{E}}$ & 0.70 & 0.77 & 0.75 & 0.84 & 0.66 & 0.71 & 0.83 & 0.74 & 0.55 & 0.75 & 0.73 \\
\hline & $f^{\circ}$ & 0.02 & 0.04 & 0.00 & -0.04 & 0.04 & 0.00 & 0.07 & $0.15^{*}$ & 0.06 & 0.06 & 0.03 \\
\hline \multirow[t]{5}{*}{ ZH (52) } & $N_{\mathrm{A}}$ & 8 & 6 & 10 & 7 & 6 & 6 & 7 & 10 & 7 & 8 & 7.50 \\
\hline & $A R$ & 6.5 & 4.9 & 8.5 & 5.6 & 4.6 & 4.8 & 5.1 & 8.1 & 5.2 & 6.1 & 5.94 \\
\hline & $H_{\mathrm{E}}$ & 0.60 & 0.80 & 0.85 & 0.62 & 0.73 & 0.76 & 0.90 & 0.84 & 0.71 & 0.65 & 0.75 \\
\hline & $H_{\mathrm{O}}$ & 0.47 & 0.69 & 0.91 & 0.72 & 0.84 & 0.78 & 0.90 & 0.41 & 0.50 & 0.53 & 0.68 \\
\hline & $f$ & $0.23 *$ & 0.15 & -0.06 & -0.16 & -0.17 & -0.02 & 0.00 & $0.52 *$ & $0.29^{*}$ & $0.18 *$ & 0.00 \\
\hline \multirow[t]{5}{*}{ QD (56) } & $N_{\mathrm{A}}$ & 6 & 6 & 9 & 8 & 6 & 8 & 7 & 8 & 7 & 9 & 7.40 \\
\hline & $A R$ & 4.6 & 4.5 & 7.5 & 6.2 & 4.6 & 6.5 & 5.4 & 6.1 & 5.3 & 7.5 & 5.82 \\
\hline & $H_{\mathrm{E}}$ & 0.64 & 0.71 & 0.77 & 0.69 & 0.73 & 0.82 & 0.88 & 0.79 & 0.54 & 0.64 & 0.72 \\
\hline & $H_{\mathrm{O}}^{\mathrm{E}}$ & 0.60 & 0.55 & 0.79 & 0.63 & 0.79 & 0.74 & 0.94 & 0.69 & 0.44 & 0.58 & 0.70 \\
\hline & $f^{\circ}$ & 0.06 & $0.18^{*}$ & -0.03 & $0.10^{*}$ & -0.08 & $0.10^{*}$ & -0.06 & 0.12 & $0.08^{*}$ & $0.09 *$ & 0.02 \\
\hline
\end{tabular}

$\mathrm{DL}=$ wild population from Dalian; $\mathrm{LYG}=$ wild population from Lianyungang; $\mathrm{NB}=$ wild population from Ningbo; $\mathrm{PT}=$ wild population from Pingtan; $\mathrm{ZH}=$ cultured population from Zhuanghe; $\mathrm{QD}=$ cultured population from Qingdao. $\mathrm{N}=$ number of samples; $N_{\mathrm{A}}=$ allele number; $A R=$ allele richness; $H_{\mathrm{E}}=$ expected heterozygosity; $H_{\mathrm{O}}=$ observed heterozygosity; $f=$ fixation index. Table-wide significance levels were applied using the sequential Bonferroni's technique $(k=9)$. *Significant at $\mathrm{P}<0.005$.

Table 3. Effective population size $\left(N_{\mathrm{E}}\right)$ estimates for Chinese hatchery populations of Ruditapes philippinarum.

\begin{tabular}{lccc}
\hline Population & Mean $F_{k}$ & $N_{\text {E }}$ & $95 \%$ CI for $N_{\text {E }}$ \\
\hline ZH & 0.102 & 59.9 & $25.6,56.8$ \\
QD & 1.189 & 48.2 & $38.7,79.6$ \\
\hline
\end{tabular}

$F_{k}=$ standard variance in allele frequency change; $\mathrm{CI}=$ confidence interval. $\mathrm{ZH}=$ Zhuanghe; $\mathrm{QD}=$ Qingdao.

Table 4. Analysis of genetic differentiation between pairs of samples based on estimates of $F_{\mathrm{ST}}$ (below diagonal) and $R_{\mathrm{ST}}$ (above diagonal).

\begin{tabular}{|c|c|c|c|c|c|c|}
\hline & DL & LYG & NB & PT & $\mathrm{ZH}$ & QD \\
\hline DL & - & $0.3152 *$ & $0.4125^{*}$ & $0.5478 *$ & $0.0811^{*}$ & $0.1365^{*}$ \\
\hline LYG & $0.0574 *$ & - & $0.1245^{*}$ & $0.1589^{*}$ & $0.1305^{*}$ & $0.0825^{*}$ \\
\hline NB & $0.0692 *$ & $0.0342 *$ & - & $0.1421 *$ & $0.1345^{*}$ & $0.0896^{*}$ \\
\hline PT & $0.0789 *$ & $0.0568 *$ & $0.0518^{*}$ & - & $0.4136^{*}$ & $0.3021^{*}$ \\
\hline $\mathrm{ZH}$ & $0.0356 *$ & $0.0412^{*}$ & $0.0489 *$ & 0.0698* & - & $0.1123^{*}$ \\
\hline QD & $0.0468 *$ & $0.0345^{*}$ & $0.0369 *$ & $0.0561 *$ & $0.0321 *$ & - \\
\hline
\end{tabular}

$\mathrm{DL}=$ Dalian; $\mathrm{LYG}=$ Lianyungang; $\mathrm{NB}=$ Ningbo; $\mathrm{PT}=$ Pingtan; $\mathrm{ZH}=$ Zhuanghe; $\mathrm{QD}=$ Qingdao. *Significant at $\mathrm{P}<0.05$. 


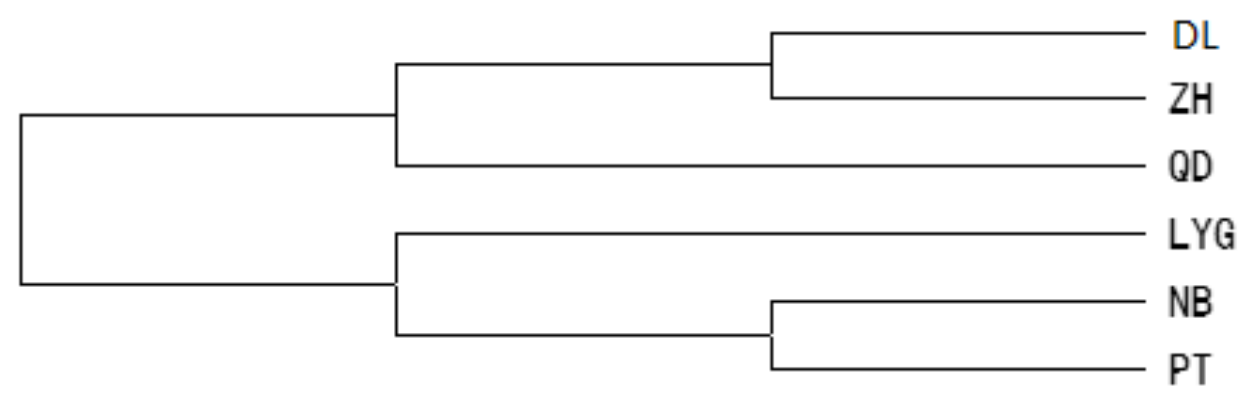

Figure 2. Neighbor-joining phylogenetic tree constructed with $F_{\mathrm{ST}}$ genetic distances. For abbreviations, see Table 2.

\section{DISCUSSION}

A high level of genetic diversity is essential for long-term survival of populations, since the extent of variation determines their ability to adapt to changing environments. In this study, substantial loss of allelic diversity was observed in two hatchery stocks compared to the natural populations. Loss of allelic variation at microsatellite loci in hatchery-produced animals has been reported in many aquaculture species, including fish (Sekino et al., 2002), shrimp (Xu et al., 2001) and shellfish (Wang et al., 2007; Li et al., 2004, 2007b). Manila clam possesses a thousand year aquaculture history in China, so there were concerns that genetic variability might have been lost during cumulative hatchery production. Bottleneck analysis showed that two cultured clam populations might have experienced a recent bottleneck, suggesting that these cultured stocks may have been set up by using only a few founder individuals, or an effective population size much lower than the real one due to lower and different contributions of founders to offspring, or due to different fitness of larvae/juveniles from different families. Clearly, the management practices used to produce these $R$. philippinarum commercial stocks would not have been sufficient to maintain genetic variability in the long run. Our results highlight the need to regularly expand hatchery stock genetic pools with additional wild collections to maintain genetically healthy $R$. philippinarum stocks in Chinese hatcheries.

In this study, we detected that 18 of the 60 population-locus tests deviated from HWE, all due to heterozygote deficiency. Generally, causes for such deviations include substructuring of the population sample, inbreeding, or the presence of null alleles. High frequency of null alleles has been reported in various bivalve mollusks (Zhan et al., 2007; Li et al., 2012a,b), and may complicate many types of population genetic analysis that rely on HWE, as false homozygotes would be common. Beyond the existence of null alleles, the heterozygote deficiency can increase due to other factors, such as nonrandom mating, admixture of independent populations, or artificial and natural selection during seed production and cultivation (Selkoe and Toonen, 2006). HWE deviation occurred more frequently in hatchery stocks than in the wild samples (Table 2). This could be the result of the long history of clam aquaculture and admixture of genetically differentiated populations. Since China has a long history of clam aquaculture, several batches of wild clams have been introduced to hatchery stocks to expand the gene pool. Repeated interbreeding between a natural population and hatchery stocks could result in a non-random mating system that could generate within-population substructuring (Wahlund effect), possibly leading to a characteristic heterozygote deficiency (Hartl and Clark, 1990). 
Pairwise comparison of the allele frequencies $\left(F_{\mathrm{ST}}\right.$ and $\left.R_{\mathrm{ST}}\right)$ showed significant differentiation between all the populations tested. Possibly, the differentiation shown by the cultured strains is due to the low number of founding individuals in hatcheries, increasing the possibility of genetic drift. This has been well documented in other species such as Pacific oyster (Hedgecock and Sly, 1990), sea trout (Was and Wenne, 2002), Japanese flounder (Sekino et al., 2002), and Japanese scallop (Li et al., 2007b). However, some hatchery operations may also have led to changes in the genetic composition of cultured strains compared with source populations. An NJ phylogenetic tree based on $F_{\mathrm{ST}}$ showed a clear separation of the northern and southern populations. The large differentiation between wild populations may be related to the geographic separation of these populations. Therefore, we propose that future breeding programs should avoid farming in areas where local spawning occurs, and introgression between cultured and wild populations should be prohibited. Because of significant genetic differentiation between northern and southern populations, cultured populations should be managed separately, and any translocation between the two areas should be avoided.

\section{ACKNOWLEDGMENTS} \#31101899).

Research supported by the National Science Foundation of China (\#41006079 and

\section{REFERENCES}

An HS, Kim EM and Park JY (2009). Isolation and characterization of microsatellite markers for the clam Ruditapes philippinarum and cross-species amplification with the clam Ruditapes variegate. Conserv. Genet. 10: 1821-1823.

Boudry P, Collet B, Cornette F, Hervouet V, et al. (2002). High variance in reproductive success of the Pacific oyster (Crassostrea gigas, Thunberg) revealed by microsatellite-based parentage analysis of multifactorial crosses. Aquaculture 204: 283-296.

Dieringer D and Schlötterer C (2003). Microsatellite analyser (MSA): A platform independent analysis tool for large microsatellite data sets. Mol. Ecol. Notes 3: 167-169.

Excoffier L, Laval G and Schneider S (2005). Arlequin (version 3.0): an integrated software package for population genetics data analysis. Evol. Bioinform. Online 1: 47-50.

Goudet J (2001). Fstat, a Program to Estimate and Test Gene Diversities and Fixation Indices (Version 2.9.3). Available at [http://www.Unil.Ch/izea/softwares/fstat.Html]. Accessed 2001.

Hara M and Sekino M (2007). Genetic differences between hatchery stocks and natural populations in Pacific abalone (Haliotis discus) estimated using microsatellite DNA markers. Mar. Biotechnol. 9: 74-81.

Hartl DL and Clark AG (1990). Principles of Population Genetics. Sinauer Associates, Sunderland.

Hedgecock D and Sly F (1990). Genetic drift and effective population sizes of hatchery-propagated stocks of the Pacific oyster Crassostrea gigas. Aquaculture 88: 21-38.

Launey S, Ledu C, Boudry P, Bonhomme F, et al. (2002). Geographic structure in the European flat oyster (Ostrea edulis L.) as revealed by microsatellite polymorphism. J. Hered. 93: 331-351.

Li HJ, Liu X and Zhang GF (2012a). Development and linkage analysis of 104 new microsatellite markers for bay scallop (Argopecten irradians). Mar. Biotechnol. 14: 1-9.

Li HJ, Liu X and Zhang GF (2012b). A consensus microsatellite-based linkage map for the hermaphroditic bay scallop (Argopecten irradians) and its application in size-related QTL analysis. PLoS One 7: e46926.

Li HJ, Liu X, Hu JJ, Bao ZM, et al. (2007a). A set of polymorphic microsatellite loci for the bay scallop, Argopecten irradians. Mol. Ecol. Notes 7: 422-424.

Li Q, Park C, Endo T and Kijima A (2004). Loss of genetic variation at microsatellite loci in hatchery strains of the Pacific abalone (Haliotis discus hannai). Aquaculture 235: 207-222.

Li Q, Xu KF and Yu RH (2007b). Genetic variation in Chinese hatchery populations of the Japanese scallop (Patinopecten yessoensis) inferred from microsatellite data. Aquaculture 269: 211-219. 
Marchant S, Haye PA, Marín SA and Winkler FM (2009). Genetic variability revealed with microsatellite markers in an introduced population of the abalone Haliotis discus hannai Ino. Aquac. Res. 40: 298-304.

Norris AT, Bradley DG and Cunningham EP (1999). Microsatellite genetic variation between and within farmed and wild Atlantic salmon (Salmo salar) populations. Aquaculture 180: 247-264.

Raymond M and Rousset F (1995). Genepop (version 1.2): population genetics software for exact tests and ecumenicism. J. Hered. 86: 248-249.

Rice WR (1989). Analyzing tables of statistical tests. Evolution 43: 223-225.

Sekino M, Hara M and Taniguchi N (2002). Loss of microsatellite and mitochondrial DNA variation in hatchery strains of Japanese flounder Paralichthys olivaceus. Aquaculture 213: 101-122.

Selkoe KA and Toonen RJ (2006). Microsatellites for ecologists: a practical guide to using and evaluating microsatellite markers. Ecol. Lett. 9: 615-629.

Slatkin M (1995). A measure of population subdivision based on microsatellite allele frequencies. Genetics 139: 457-462.

Tamura K, Dudley J, Nei M and Kumar S (2007). MEGA4: Molecular Evolutionary Genetics Analysis (MEGA) software version 4.0. Mol. Biol. Evol. 24: 1596-1599.

Wang LL, Zhang H, Song LS and Guo XM (2007). Loss of allele diversity in introduced populations of the hermaphroditic bay scallop Argopecten irradians. Aquaculture 271: 252-259.

Was A and Wenne R (2002). Genetic differentiation in hatchery and wild sea trout (Salmo trutta) in the Southern Baltic at microsatellite loci. Aquaculture 204: 493-506.

Weber JL and May PE (1989). Abundant class of human DNA polymorphisms which can be typed using the polymerase chain reaction. Am. J. Hum. Genet. 44: 388-396.

Weir BS and Cockerham CC (1984). Estimating F-statistics for the analysis of population structure. Evolution 38 : 1358-1370.

Xu Z, Primavera JH, de la Pena LD, Pettit P, et al. (2001). Genetic diversity of wild and cultured black tiger shrimp (Penaeus monodon) in the Philippines using microsatellites. Aquaculture 199: 13-40.

Yasuda N, Nagai S, Yamaguchi S, Lian CL, et al. (2007). Development of microsatellite markers for the Manila clam Ruditapes philippinarum. Mol. Ecol. Notes 7: 43-45.

Zhan AB, Bao ZM, Hui M, Wang ML, et al. (2007). Inheritance pattern of EST-SSRs in self-fertilized larvae of the bay scallop Argopecten irradians. Ann. Zool. Fennici 44: 259-268.

Zhang GF and Yan XW (2006). A new three-phase culture method for Manila clam, Ruditapes philippinarum, farming in northern China. Aquaculture 258: 452-461. 